\title{
Leukocyte Elastase Release during Blood Coagulation
}

\author{
A POTENTIAL MECHANISM FOR ACTIVATION OF THE ALTERNATIVE \\ FIBRINOLYTIC PATHWAY
}

\author{
Edward F. Plow, Department of Molecular Immunology, Research Institute of \\ Scripps Clinic, La Jolla, California 92037
}

A B S T R A C T Immunological detection of elastase, an enzyme present within leukocyte granules, has been used as a marker for polymorphonuclear leukocyte activation. Polymorphonuclear leukocytes contained $4.6 \mu \mathrm{g} / 10^{7}$ cells, whereas erythrocytes, mononuclear cells, and platelets contained $<1 \%$ of this level. In plasma that was separated from blood cells after $1 \mathrm{~h}$ at $22^{\circ} \mathrm{C}$, the mean level of elastase-related antigen in seven normal donors was $25 \pm 6 \mathrm{ng} / \mathrm{ml}$. This level was unaltered by immediate separation of the plasma from the cells, by inclusion of protease inhibitors, or by anticoagulation of the plasma with either EDTA or acidcitrate-dextrose (the level in heparinized plasma was approximately threefold higher). In serum, the level of elastase-related antigen was $288 \pm 125 \mathrm{ng} / \mathrm{ml}$, representing an 11.5-fold increase above plasma levels. The antigen detected in serum was immunochemically indistinguishable from the leukocyte enzyme. Release of elastase was observed when isolated polymorphonuclear leukocytes were added to nonanticoagulated platelet-rich or platelet-poor plasma, recalcified plasma, or to serum. Addition of a chelating agent to serum prevented elastase release, but calcium or magnesium did not induce release in the absence of plasma. Coagulation induced by addition of thrombin to plasma also failed to induce release. In whole blood or in anticoagulated plasma reconstituted with polymorphonuclear leukocytes and then recalcified, initial release of elastase occurred concomitantly with or slightly after clotting and reached maximal levels within 20$40 \mathrm{~min}$ after clot formation. The data indicates that early events in coagulation or other pathways that occur in parallel with coagulation induce leukocyte release. The release of elastase, a major fibrinolytic protease of leukocytes, from the cells provides a mechanism

Portions of this study were presented at the 5th International Conference on Synthetic Fibrinolytic Thrombolytic Agents, Malmo, Sweden, June 1980.

Received for publication May 1981 and in revised form 26 October 1981. for this enzyme or other granule proteases to participate in physiological events.

\section{INTRODUCTION}

Dissolution of the fibrin clot by enzymes with fibrinolytic activity is required to restore integrity to intravascular and extravascular sites of thrombus formation. Plasmin is the primary fibrinolytic pathway of plasma, but cells including platelets (1) and neutrophils (2-5) also contain fibrinolytic proteases. $\mathrm{Nu}$ merous studies dating from the observations of Rulot (6) in 1904 and Opie (7) in 1907 have demonstrated that leukocytes are capable of degrading fibrin and fibrinogen substrates. Evidence consistent with the participation of leukocytes in physiologic fibrinolysis includes: $(a)$ the preferential accumulation of leukocytes within thrombi relative to their blood concentration $(8) ;(b)$ the ability of the cells to readily penetrate preformed thrombi (9); and (c) the direct interaction with and internalization of fibrin by leukocytes as visualized by immunofluorescence and electron microscopy (10). The fibrinolytic proteases of the leukocyte reside primarily within secretory granules (4), and cell lysis, phagocytosis, and/or secretion provide potential mechanisms for activation of the leukocyte fibrinolytic pathway.

The fibrinolytic activity of leukocyte extracts is independent of the plasminogen system as plasmin (ogen) inhibitors and activators fail to inhibit or augment fibrinolytic activity $(4,11)$ and fibrinogen degradation products generated by leukocyte proteases are structurally and immunochemically distinguishable from plasmin-derived degradation products $(4,12$, 13). A variety of neutral proteases $(5,14-18)$ and acidic cathepsins (3) of neutrophils are capable of degrading fibrin (ogen). Within leukocyte granules, elastase has been identified as one of the major fibrinolytic proteases active at neutral $\mathrm{pH}(19)$. In this study, a specific radioimmunoassay for leukocyte elastase has been de- 
veloped, and the detection of this antigen has been used as a marker for leukocyte activation. The data demonstrate that this enzyme is released from the cell in association with blood coagulation.

\section{METHODS}

Cell isolation. Human leukocytes were isolated from citrated blood by differential sedimentation in $1 \%$ dextran followed by brief hypotonic or $\mathrm{NH}_{4} \mathrm{Cl}$ lysis of residual erythrocytes $(4,20)$. The isolated cells consisted of $75-85 \%$ polymorphonuclear leukocytes (PMN) ${ }^{1}$ and $10-20 \%$ mononuclear cells. Other cell types and purer preparations of PMN were isolated by placing 10-ml aliquots of heparinized blood onto $3 \mathrm{ml}$ of Ficoll-Hypaque (density $1.074 \mathrm{~g} / \mathrm{cm}^{3}$ ) and centrifuging at $2,260 \mathrm{~g}$ for $6 \mathrm{~min}$ at $20^{\circ} \mathrm{C}$. Mononuclear cells were removed from the interface and washed three to five times in PBS. Erythrocytes and PMN were recovered from the pellets of the Ficoll-Hypaque gradient and separated by dextran sedimentation and $\mathrm{NH}_{4} \mathrm{Cl}$ lysis. The purity of the isolated cells determined by neutral red and Giemsa staining was as follows: the mononuclear cells contained $80-85 \%$ lymphocytes, 10-20\% monocytes with $<2 \%$ PMN; PMN contained $\leq 3 \%$ mononuclear cells, and $\leq 0.1 \%$ erythrocytes; the erythrocytes contained $\leq 0.05 \%$ PMN. Platelets were prepared by differential centrifugation followed by gel filtration $(21)$ and contained $\leq 0.05 \%$ PMN.

Isolation of leukocyte elastase. Leukocyte granules were isolated by differential ultracentrifugation (22) and disrupted by repeated freezing and thawing. The extracts were applied to a $2.5 \times 40-\mathrm{cm}$ column of CM-Sephadex C50 (Pharmacia Fine Chemicals, Piscataway, N. J.) equilibrated with $0.1 \mathrm{M} \mathrm{NaCl}, 0.05 \mathrm{M}$ sodium phosphate, $\mathrm{pH} 7.2$, and a linear gradient was developed with a final buffer of $1.0 \mathrm{M}$ $\mathrm{NaCl}, 0.05 \mathrm{M}$ sodium phosphate, pH 7.2. Fractions containing elastase activity, identified by hydrolysis of the $N$-tBOCL-alanine- $p$-nitro-phenylester (23) were concentrated by ammonium sulfate precipitation at $80 \%$ saturation, and applied to a $1.5 \times 20-\mathrm{cm}$ column of elastin-Sepharose $(20 \mathrm{mg}$ elastin/ $\mathrm{ml}$ Sepharose) at $4^{\circ} \mathrm{C}(24)$. After extensive washing with buffers containing $0.15 \mathrm{M}$ and $1.0 \mathrm{M} \mathrm{NaCl}$, the purified elastase was eluted with $8.0 \mathrm{M}$ urea and dialyzed against 0.15 $\mathrm{M} \mathrm{NaCl}, 0.035 \beta$-alanine, $0.025 \mathrm{M}$ sodium pyrophosphate, pH 5.9 .

Radioimmunoassay for leukocyte elastase. Leukocyte elastase was radioiodinated by a microvolume chloramine$\mathrm{T}$ procedure (25). Elastase, $15 \mu \mathrm{g}$ in $100 \mu \mathrm{l}, 50 \mu \mathrm{l}$ of $0.2 \mathrm{M}$ sodium phosphate buffer, $\mathrm{pH} 7.2,2 \mathrm{mCi}$ carrier-free $\mathrm{Na}^{125} \mathrm{I}$ (1 mCi $/ \mu g{ }^{125} \mathrm{I}$, Amersham Corp., Arlington Heights, Ill.) and $20 \mu \mathrm{g}$ chloramine-T in $10 \mu \mathrm{l}$ PBS were incubated for $5 \mathrm{~min}$ at $22^{\circ} \mathrm{C}$. The reaction was stopped by addition of $23 \mu \mathrm{g}$ sodium metabisulfite in $10 \mu \mathrm{l}$, and $100 \mu \mathrm{l}$ of $1 \% \mathrm{KI}$ and $100 \mu \mathrm{l}$ of $1 \%$ bovine serum albumin were added. Phenylmethylsulfonylfluoride or diisopropylfluorophosphate (DFP) were added to final concentrations of $2 \mathrm{mM}$; and after 30 min at $22^{\circ} \mathrm{C}$, free ${ }^{125} \mathrm{I}$ was removed by extensive dialysis or gel filtration of Sephadex G25. The radioactivity of ${ }^{125}$ I-elastase was $92 \%$ precipitable in $10 \%$ trichloroacetic acid, and its sp act was $3-10 \mu \mathrm{Ci} / \mu \mathrm{g}$.

Antiserum to leukocyte elastase was prepared in rabbits

${ }^{1}$ Abbreviations used in this paper: $\mathrm{PMN}$, polymorphonuclear leukocytes; $A C D$, acid-citrate-dextrose (1\% dextrose, $0.063 \mathrm{M}$ citrate buffer, $\mathrm{pH} 4.55$ ); $\mathrm{PBS}, 0.15 \mathrm{M} \mathrm{NaCl}, 0.01 \mathrm{M}$ phosphate buffer, pH 7.3; DFP, diisopropylfluorophosphate. by injecting $100-\mu \mathrm{g}$ doses in complete Freund's adjuvant at multiple intradermal sites on a weekly basis. Serum was collected $1 \mathrm{wk}$ after the fourth booster injection. The radioimmunoassay for leukocyte elastase was of the double-antibody type (26). ${ }^{125} \mathrm{I}$-elastase was added at $15 \mathrm{ng} / \mathrm{ml}$ in a $0.25-\mathrm{ml}$ vol, followed by the test sample in a 1.0 -ml addition and $0.25 \mathrm{ml}$ of diluted antielastase. The buffer system was 0.6 $\mathrm{M} \mathrm{NaCl}, 0.05 \mathrm{M}$ sodium borate buffer, $\mathrm{pH} \mathrm{8.3,} \mathrm{containing}$ $2 \mathrm{mM}$ EDTA, $20 \mathrm{U}$ aprotinin and heparin $/ \mathrm{ml}$, and $2 \%$ heatinactivated normal rabbit serum. Nonspecific precipitation of ${ }^{125}$ I-elastase by the second antibody was $<5 \%$, and results were routinely corrected for the precipitability of the ligand in $10 \%$ trichloroacetic acid.

Assays of PMN function. The leukocyte release reaction was induced with serum-activated zymosan particles (ICN Nutritional Biochemicals, Cleveland, Ohio) prepared as described (4). Leukocytes, $1 \times 10^{7}$ cells in $1 \mathrm{ml}$ of Puck saline $\mathrm{G}$, were added to $10 \mathrm{mg}$ of serum-activated or control particles (prepared in an identical manner without serum activation) and incubated for $30 \mathrm{~min}$ at $37^{\circ} \mathrm{C}$ with agitation. Cells and particles were removed by centrifugation at 800 $g$ for $10 \mathrm{~min}$, and elastase antigen was measured in the suppernatant. Percent release was calculated relative to the elastase solubilized by repeated freezing and thawing of leukocytes. Lactic dehydrogenase was used as a marker of cell lysis and was measured by the rate of NAD reduction $(4,27)$.

For ${ }^{51} \mathrm{Cr}$ labeling of leukocytes, PMN isolated by centrifugation through Ficoll-Hypaque gradients followed by dextran sedimentation were used. PMN $\left(5 \times 10^{8}\right.$ cells $)$ were suspended in $1 \mathrm{ml} \mathrm{PBS}$ and $200 \mu \mathrm{Ci}^{51} \mathrm{Cr}$ (New England Nuclear, Boston, Mass.) was added. After a 30 -min incubation at $37^{\circ} \mathrm{C}$, $9 \mathrm{ml}$ PBS was added, and the cells were centrifuged through $3 \mathrm{ml}$ Ficoll-Hypaque. This washing procedure was repeated once followed by three additional washes in $0.15 \mathrm{M} \mathrm{NaCl}$, $0.01 \mathrm{M}$ phosphate buffer, pH 7.3 (PBS).

Centrifugation-induced release was assessed by fixing the PMN with paraformaldehyde before centrifugation. Calcium was added to one of two identical aliquots of PMN $\left(10^{7} / \mathrm{ml}\right)$ in acid-citrate-dextrose (ACD) plasma, and after $\mathrm{l} h$ at $37^{\circ} \mathrm{C}$, the clot was wrung and removed from the recalcified sample. Paraformaldehyde (4\% in PBS) was added to both samples to a final $2 \%$ concentration; and after $1 \mathrm{~h}$ at $37^{\circ} \mathrm{C}$, an equal volume of $0.2 \mathrm{M}$ Tris, $\mathrm{pH} 7.2$, was added. After $10 \mathrm{~min}$, the cells were recovered by centrifugation and tested for their capacity to undergo release with zymosan particles.

Analytical procedures. Polyacrylamide gel electrophoresis was performed on $7.5 \%$ gels in the presence of sodium dodecylsulfate (SDS) under nonreducing conditions (28). Double immunodiffusion analysis was performed in $1 \%$ agarose in PBS. Blood was drawn by venepuncture into plastic syringes or evacuated tubes containing $1.5 \mathrm{mg}$ either $K_{3}$ EDTA, 15 USP U heparin or $0.14 \mathrm{ml} \mathrm{ACD-solution} \mathrm{per}$ milliliter of blood. Removal of cells or clots was achieved by centrifugation at $1,200 \mathrm{~g}$ for $10 \mathrm{~min}$ at $22^{\circ} \mathrm{C}$.

\section{RESULTS}

Elastase was isolated from leukocyte granules by ion exchange and affinity chromatography. The isolated enzyme yielded a single band on SDS polyacrylamide gels under nonreducing condition (Fig. 1), and a mol wt of 30,000 was estimated from its mobility relative to protein standards. When radioiodinated to a sp act 

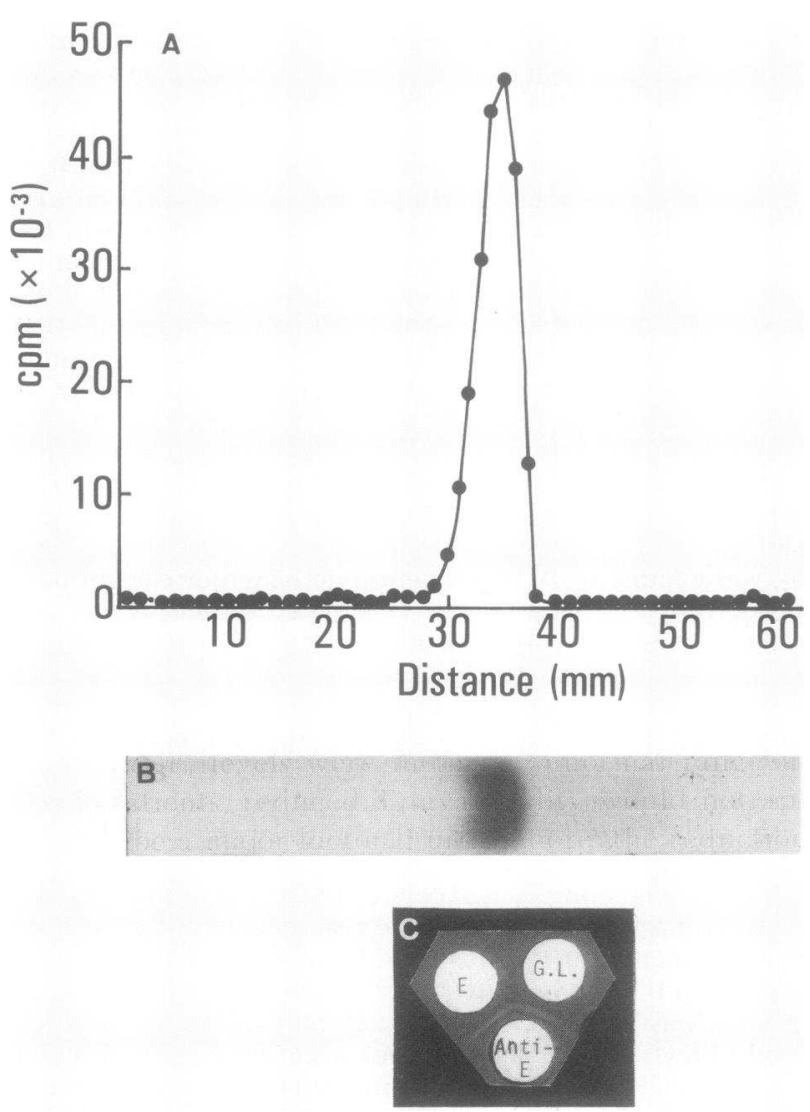

Figure 1 Characterization of labeled and nonlabeled leukocyte elastase and its rabbit antiserum. Panel A. Gel slices (1 $\mathrm{mm}$ ) of a $10 \%$ polyacrylamide gel in sodium dodecylsulfate on which $250,000 \mathrm{cpm}$ of ${ }^{125} \mathrm{I}$-elastase was electrophoresed. Panel B. A polyacrylamide gel run in parallel on which $50 \mu \mathrm{g}$ nonlabeled elastase was applied, and the gel stained with Coomassie Blue. In both gels, the tops are to the left and have been aligned. Panel $C$. Immunodiffusion of the rabbit antiserum to elastase (anti-E) vs. isolated elastase (E) and an extract of isolated leukocyte granules (G.L.). Each well contained $100 \mu \mathrm{l}$ of sample with the elastase at 200 $\mu \mathrm{g} / \mathrm{ml}$, and the granule lysate was isolated from $10^{8}$ cells/ $\mathrm{ml}$.

of $5 \mu \mathrm{Ci} / \mu \mathrm{g},>95 \%$ of the radioactivity migrated as a single peak on a SDS polyacrylamide gel with a mobility identical to that of the stained protein (Fig. $1 \mathrm{~A}$ and B). Antiserum to leukocyte elastase, raised in rabbits, formed a single precipitin line with isolated elastase and with the extract of leukocyte granules, and these precipitin lines fused in a reaction of complete antigenic identity (Fig. 1C).

For quantitation of leukocyte elastase, a competitive inhibition radioimmunoassay of the double antibody type was developed. As shown in Fig. 2, nonlabeled elastase yielded a typical semilogarithmic inhibition profile producing complete competitive inhibition at $50 \mathrm{ng} / \mathrm{ml}$ and $50 \%$ relative inhibition at $3 \mathrm{ng} / \mathrm{ml}$. Dur- ing the course of this study, the limit of sensitivity of the radioimmunoassay ( $10 \%$ relative inhibition) was $0.47 \pm 0.36 \mathrm{ng} / \mathrm{ml}$. A soluble extract of leukocyte granules also produced complete competitive inhibition and yielded an inhibition slope similar to that of the isolated enzyme. This antigenic identity suggested minimal immunochemical alteration of the enzyme during isolation. Cathepsin G, purified from leukocyte granules, failed to produce inhibition at $1 \mu \mathrm{g} / \mathrm{ml}$.

The specificity of leukocyte elastase as a marker for PMN and their activation was assessed with respect to: (a) restriction of elastase-related antigen to the PMN as contrasted to other cells, and $(b)$ the capacity to detect secretion of elastase from stimulated leukocytes. Human peripheral blood cells were fractionated into PMN, platelet, erythrocyte, and mononuclear cell populations, and the elastase-related antigen in the detergent-solubilized extracts of the cells was quantitated by radioimmunoassay. As shown in Table I, the PMN extract contained at least 130 -fold more elastase-related antigen than the other cell populations. Thus, the low levels of elastase-related antigen detected in other cell populations could be accounted for by less than a $1 \%$ PMN contamination. The level of $4.6 \mu \mathrm{g} / 10^{7}$ PMN is within the range of $\sim 1-12 \mu \mathrm{g}$ elastase $/ 10^{7}$ PMN reported by others $(16,29)$.

The capacity to detect the nonlytic release of elastase-related antigen from PMN was assessed by using serum-activated zymosan particles to stimulate leukocyte secretion. Activated zymosan stimulated release of elastase-related antigen from the PMN of all five individual donors tested. Calculated relative to freeze-

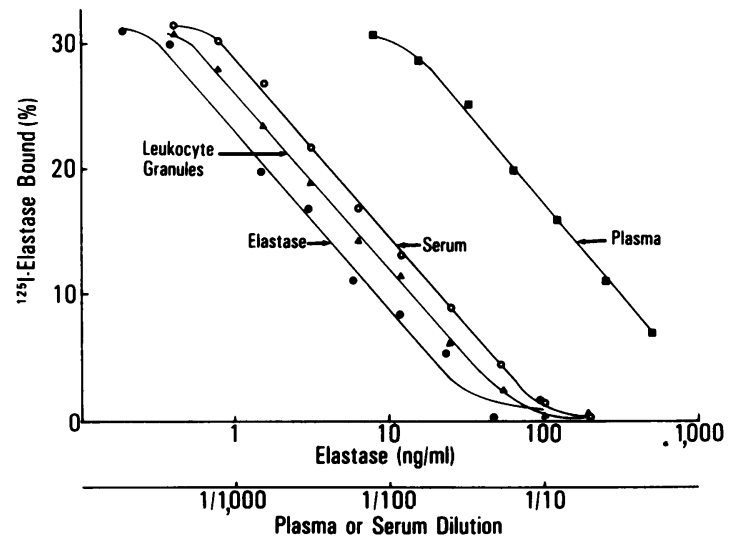

FIgURE 2 Competitive inhibition radioimmunoassay comparing the standard inhibition curve of purified leukocyte elastase with those produced by extracts of leukocyte granules, plasma, and serum. The undiluted granule extract was derived from $10^{7}$ leukocytes. The plasma and serum samples were from the same donor, and the plasma anticoagulant was ACD. ${ }^{125} \mathrm{I}$-elastase was present at a final concentration of $2.5 \mathrm{ng} / \mathrm{ml}$. 
TABLE I

Quantitation of Elastase-related Antigen in the DetergentSoluble Extracts of Isolated Peripheral Blood Cells ${ }^{\circ}$

\begin{tabular}{lc}
\hline \multicolumn{1}{c}{ Cell type } & Elastase-related antigen \\
\hline & $n g / 10^{7}$ cells \\
PMN & 4,600 \\
Platelets & $<0.08$ \\
Erythrocytes & 1.5 \\
Mononuclear cells & 33.5 \\
\hline
\end{tabular}

- Cells were extracted with $1.0 \%$ Triton-X100 and the solubilized elastase-related antigen was quantitated by radioimmunoassay.

thaw controls, $39.1 \pm 27.1 \%$ of the antigen was released by the activated zymosan as contrasted to a $7 \pm 5.1 \%$ release induced by the unactivated zymosan particles. Although the zymosan-induced release of elastase was quite variable among the donors, each individual cell preparation exhibited at least a threefold increase above the corresponding sample treated with unactivated zymosan. As a control for cytolysis, lactic acid dehydrogenase activity was measured; and; with both activated and nonactivated zymosan, $<4 \%$ of total cellular content was solubilized. These results indicate that elastase-related antigen is restricted to the PMN and that its secretion may be detected and quantitated.

With these assurances of specificity and sensitivity, the levels of elastase-related antigen in serum and plasma of normal donors was assessed. Blood samples were drawn into ACD anticoagulant or no anticoagulant and incubated for $1 \mathrm{~h}$ at $22^{\circ} \mathrm{C}$ before removal of the blood clots and/or cells by centrifugation to obtain the serum and plasma samples. Elastase-related antigen was detected in all plasmas (seven donors) at the low level of $25 \pm 6 \mathrm{ng} / \mathrm{ml}$. In contrast, a mean of $288 \pm 125 \mathrm{ng}$ elastase $/ \mathrm{ml}$ was detected in the sera, representing a mean increase of 11.5 -fold over plasma levels. This increase was observed in all clotted samples and ranged from a 4.4- to a 20.0 -fold increase. The competitive inhibition produced by serial dilutions of a serum and plasma sample from the same donor in the radioimmunoassay are included in Fig. 2. At low dilution, the serum sample produced complete competitive inhibition and yielded an inhibition slope parallel to that of isolated leukocyte elastase. The plasma sample contained insufficient elastase-related antigen to produce complete inhibition but also yielded a slope parallel to the isolated enzyme. In separate experiments (not shown), it was demonstrated that addition of isolated leukocyte elastase or elastase inactivated with DFP to serum or plasma generated superimposable inhibition curves, indicating that the capacity to detect elastase-related antigen in enzymatically active or nonactive form was equivalent in plasma and serum.
The data indicated that low levels of elastase-related antigen were present in normal plasma and that when blood was permitted to clot, the level of elastase-related antigen in the resultant serum increased markedly. The basis for the elastase-related antigen in plasma was further investigated by examining the effects of anticoagulants and incubation time. Venous blood was drawn into ACD, EDTA, or heparin, as well as into the combination of these anticoagulants supplemented with the protease inhibitors, 6-aminohexanoic acid, aprotinin, and hirudin, and incubated $1 \mathrm{~h}$ at $22^{\circ} \mathrm{C}$ before separation of the plasma. In addition, blood drawn into the combination of anticoagulants and protease inhibitors was immediately centrifuged at $4^{\circ} \mathrm{C}(10 \mathrm{~min}$ required for plasma separation). The blood drawn into ACD, EDTA, or the combination of anticoagulants and inhibitors contained very similar levels of elastase-related antigen (Table II). The quantity of elastase-related antigen in heparinized plasma was approximately threefold higher than in the other anticoagulants. Immediate separation of the blood drawn into the combination of anticoagulants and inhibitors did not diminish the plasma elastase level. Thus, normal plasma appeared to contain a basal level of leukocyte elastase-related antigen that could not be attributed to in vitro liberation of the enzyme from leukocytes.

The increase in serum elastase-related antigen was further characterized by experiments in which celldepleted plasma samples were reconstituted with PMN. Isolated PMN were added to ACD plasma, nonanticoagulated plasma (both platelet-rich and plateletpoor plasma), serum, or serum to which ACD was

TABLE II

Effect of Anticoagulants, Protease Inhibitors, and Incubation on the Plasma Level of Elastase-related Antigen ${ }^{\circ}$

\begin{tabular}{lr}
\hline \multicolumn{1}{c}{ Anticoagulant } & Elastase \\
& $n g / m l$ \\
None (serum) & $307 \pm 54$ \\
ACD & $46 \pm 25$ \\
EDTA & $44 \pm 29$ \\
Heparin & $139 \pm 59$ \\
Inhibitors & $42 \pm 22$ \\
Inhibitors & \\
(no incubation) & $52 \pm 15$ \\
\hline
\end{tabular}

- Cells were separated from the blood samples after $30 \mathrm{~min}$ at $22^{\circ} \mathrm{C}$ with the exception of the last sample [inhibitors (no incubation)] in which the plasma was obtained by immediate centrifugation at $4^{\circ} \mathrm{C}$

\ These samples were drawn into plastic syringes containing ACD supplemented with $10 \mathrm{mM}$ EDTA, $0.2 \mathrm{M}$ 6-aminohexanoic acid, $100 \mathrm{U}$ aprotinin $/ \mathrm{ml}$ and $50 \mathrm{U}$ hirudin $/ \mathrm{ml}$ (final concentrations). 
added. The elastase-related antigen within the resultant plasma or serum samples was determined after a 1-h incubation at $22^{\circ} \mathrm{C}$. The data shown in Table III illustrates the following points: (a) PMN incubated in ACD plasma did not spontaneously liberate elastaserelated antigen; the elastase level within the ACD plasma incubated with cells was only 1.8 -fold greater than in the plasma without added cells. (b) In the absence of anticoagulant, the level of elastase-related antigen in the resultant serum increased markedly, and this increase was independent of the presence or absence of platelets within the plasma. (c) A similar marked increase was observed when PMN were added to serum, indicating that the factors responsible for the liberation of elastase from PMN were maintained in serum. (d) Addition of ACD to serum prevented the release of elastase, suggesting a potential role for divalent ions in liberation of the enzyme.

The relationship between divalent ions, plasma, and the release of elastase was further examined. Isolated PMN were suspended in Puck's saline A, which lacks both calcium and magnesium. Calcium, magnesium, thrombin, plasma, or combinations of the agents were added to the cell suspensions, and elastase release was measured after $1 \mathrm{~h}$ at $22^{\circ} \mathrm{C}$. As shown in Table IV, calcium, magnesium, or the combination of these divalent ions were in themselves not sufficient to induce elastase release. Similarly, thrombin alone or clotting induced by the combination of thrombin and plasma failed to liberate elastase-related antigen. Only when both plasma and calcium were added to the cells (which resulted in clot formation), was a significant increase of elastase in the soluble fraction observed.

Cell lysis or nonlytic secretion represent possible

TABLE III

Liberation of Elastase-related Antigen from Isolated PMN Added to Plasma or Serum ${ }^{\circ}$

\begin{tabular}{cc}
\hline Cells added to & $\begin{array}{c}\text { Elastase-related } \\
\text { antigen }\end{array}$ \\
\hline & $n g / m l$ \\
Anticoagulated (ACD) plasma & $47 \pm 12$ \\
Platelet-rich plasma & \\
$\quad$ (no anticoagulant) & $784 \pm 86$ \\
Platelet-poor plasma & \\
(no anticoagulant) & $1,176 \pm 120$ \\
Serum & $854 \pm 48$ \\
Serum + ACD & $88 \pm 22$ \\
\hline
\end{tabular}

- Samples were reconstituted with $10^{7}$ leukocytes per milliliter. The plasma sample without added cells contained $26 \mathrm{ng}$ elastase $/ \mathrm{ml}$. Elastase-related antigen in solution was quantitated after a $1 \mathrm{~h}$ incubation at $22^{\circ} \mathrm{C}$. The serum was obtained from plasma clotted in the absence of cells.
TABLE IV

Effect of Divalent Ions and Thrombin on the Release of Elastase-related Antigen from PMN

\begin{tabular}{lc}
\hline \multicolumn{1}{c}{ Addition to $\mathrm{PMN}^{\bullet}$} & $\begin{array}{c}\text { Elastase-related } \\
\text { antigen }\end{array}$ \\
& $n g / \mathrm{ml}$ \\
None & $14 \pm 8$ \\
Calcium, $30 \mathrm{mM}$ & $38 \pm 6$ \\
Magnesium, $30 \mathrm{mM}$ & $26 \pm 6$ \\
ACD-plasma, $50 \%$ & $21 \pm 8$ \\
ACD-plasma, $50 \%+$ calcium, & \\
$30 \mathrm{mM}$ & $650 \pm 23$ \\
Thrombin, $5 \mathrm{U} / \mathrm{ml}$ & $25 \pm 3$ \\
Thrombin, $5 \mathrm{U} / \mathrm{ml}+$ ACD & \\
plasma, $50 \%$ & $28 \pm 12$ \\
\hline
\end{tabular}

- $1 \times 10^{7} \mathrm{PMN} / \mathrm{ml}$ were suspended in Puck's Saline A, which lacks calcium and magnesium. Additions were to the final concentrations indicated in parentheses, and release of elastase-related antigen was measured after $1 \mathrm{~h}$ at $22^{\circ} \mathrm{C}$.

mechanisms for the coagulation-associated liberation of elastase from PMN. To evaluate cell lysis, ${ }^{51} \mathrm{Cr}-\mathrm{la}-$ beled PMN were suspended in Puck's saline A or ACD plasma in the presence or absence of calcium. After $\mathrm{l} \mathrm{h}$ at $22^{\circ} \mathrm{C}$, the samples were centrifuged, and the ${ }^{51} \mathrm{Cr}$ in the supernatant was measured. As shown in Table $\mathrm{V}$, only a low level of ${ }^{51} \mathrm{Cr}$ was released in the presence or absence of calcium in either suspending medium. The ${ }^{51} \mathrm{Cr}$ in the supernatants of the coagulated and noncoagulated plasma samples was 6.4 and $6.2 \%$, respectively. Quantitation of elastase-related antigen in the supernatants of these samples verified that significant release occurred only in the clotted plasma. In addition, cell viability as assessed by trypan blue exclusion was $>94 \%$ in all samples. Thus, cell lysis

TABLE V

${ }^{51}$ Cr-Release from PMN in Clotted and Nonclotted Plasma ${ }^{\circ}$

\begin{tabular}{cccc}
\hline $\begin{array}{c}\text { Suspending } \\
\text { medium }\end{array}$ & Calcium & ${ }^{\text {s1 Cr-release }}$ & $\begin{array}{c}\text { Elastase-related } \\
\text { antigen }\end{array}$ \\
\hline & $30 \mathrm{mM}$ & $\%$ & $\mathrm{ng} / \mathrm{ml}$ \\
Puck's Saline A & - & 8.0 & 42 \\
Puck's Saline A & + & 7.8 & 52 \\
ACD-plasma & - & 6.2 & 28 \\
ACD-plasma & + & 6.4 & 720 \\
\hline
\end{tabular}

- ${ }^{51} \mathrm{Cr}-\mathrm{PMN}$ were resuspended at $1 \times 10^{7} \mathrm{cells} / \mathrm{ml}$ in the indicated media with or without calcium. After $1 \mathrm{~h}$ at $22^{\circ} \mathrm{C}$ supernatant fractions were obtained by centrifugation. Percent ${ }^{51} \mathrm{Cr}$-release was calculated relative to the radioactivity solubilized by $1 \%$ Triton $\mathrm{X} 100$, and elastase-related antigen was quantitated by radioimmunoassay. 
and death could be reasonably excluded as the basis for elastase release.

The role of centrifugation in the induction of elastase release was evaluated. Two samples of PMN $\left(10^{7}\right.$ cells $/ \mathrm{ml}$ ) were placed in ACD-plasma, and clotting was induced in one by recalcification. After $1 \mathrm{~h}$ at $37^{\circ} \mathrm{C}$ the clot was wrung and removed with a wooden applicator. Paraformaldehyde was added to a final concentration of $2 \%$ to both samples, and the cells were fixed for $1 \mathrm{~h}$ at $37^{\circ} \mathrm{C}$. An equal volume of $0.2 \mathrm{M}$ Tris, pH 7.2, was then added to neutralize excess paraformaldehyde, and the cells were then removed by centrifugation. The elastase-related antigen in recalcified and fixed samples was $390 \mathrm{ng} / \mathrm{ml}$ compared with 400 $\mathrm{ng} / \mathrm{ml}$ in a sample treated in parallel but omitting the paraformaldehyde. In the nonclotted samples, these values were 32 and $28 \mathrm{ng} / \mathrm{ml}$ for the fixed and nonfixed samples, respectively. Fixation of the cells was verified by showing that the paraformaldehyde-treated cells failed to release elastase-related antigen when stimulated with activated zymosan particles. Thus, the release of elastase from the cells in association with clotting was not dependent upon centrifugation of the cells.

The rate of elastase secretion from PMN in clotting whole blood or in plasma was assessed. The results shown in Fig. 3A were obtained by incubating blood

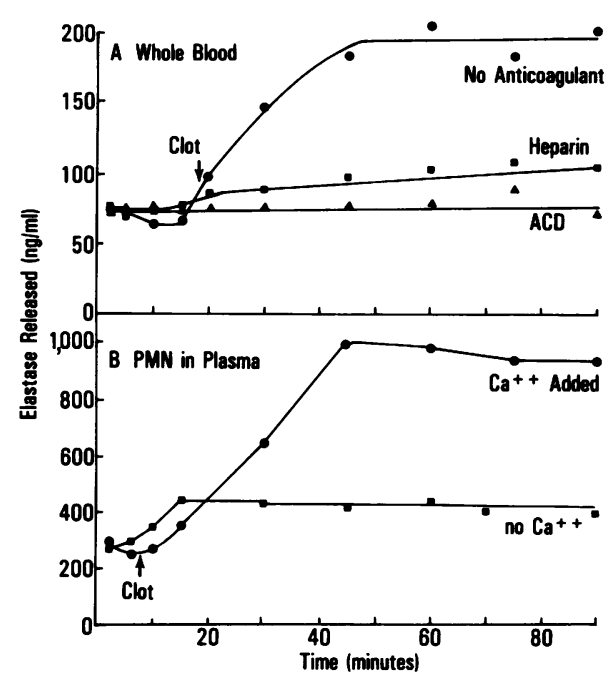

Figure 3 Time-dependent release of elastase-related antigen in whole blood or from isolated PMN in plasma. In Panel $A$, the blood was collected into heparin, ACD, or no anticoagulant; and, in Panel B, $10^{7}$ PMN were added per milliliter of ACD-plasma with or without $30 \mathrm{mM} \mathrm{CaCl}$. 1-ml aliquots of each sample were placed in $12 \times 75$ polypropylene tubes at $37^{\circ} \mathrm{C}$. At selected time points, samples were centrifuged for $10 \mathrm{~min}$ at $1,200 \mathrm{~g}$ to remove clots and/or cells, and the elastase-related antigen in the fluid phase was quantitated by radioimmunoassay. The time indicates when centrifugation was begun. in plastic tubes with heparin, $\mathrm{ACD}$, or no anticoagulant at $37^{\circ} \mathrm{C}$. In the absence of anticoagulant, clotting was detected at $19 \mathrm{~min}$, and a concomitant rise in elastaserelated antigen was observed in the serum after centrifugation. This increase reached a maximum level at $45 \mathrm{~min}$ and did not change for the next $45 \mathrm{~min}$. The elastase-related antigen in the ACD plasma remained constant for the 90-min incubation, and the heparinized plasma exhibited a slight and progressive increase. Similar results were obtained with PMN added to plasma (Fig. 3B). With addition of calcium, clotting occurred at $8 \mathrm{~min}$, and an increase in serum elastase was noted at $15 \mathrm{~min}$. This increase again reached maximal levels at $45 \mathrm{~min}$. In the absence of calcium, a slight increase in elastase-related antigen was detected between 5 and 15 min but then showed no subsequent change.

The interaction of elastase released from the PMN with plasma proteins such as protease inhibitors was evaluated in gel filtration experiments. A Sephadex G100 column $(1.5 \times 90 \mathrm{~cm})$ was calibrated with free ${ }^{125}$ I-elastase (inactivated with DFP), with ${ }^{125}$ I-elastase added to serum before gel filtration, as well as from the elution pattern of serum proteins. As shown in Fig. $4 \mathrm{~A}$, free ${ }^{125}$ I-elastase eluted as a single peak beyond the elution position of albumin, consistent with its mol wt of 30,000 . In contrast, when ${ }^{125}$ I-elastase was added to serum, no radioactivity was detected in the position of free elastase. Instead, a major peak of radioactivity eluted slightly before the albumin peak. The estimated mol wt of this peak at 80,000 is consistent with the formation of a 1:1 stoichiometric complex between elastase and its primary serum inhibitor, $\alpha_{1}$-antitrypsin (29). In addition, a smaller proportion of the radioactivity eluted at the void volume of the column, perhaps arising from complex formation between elastase and $\alpha_{2}$-macroglobulin, a second serum inhibitor of the enzyme. In Fig. 4B, serum derived $60 \mathrm{~min}$ after recalcification of PMN-rich plasma was applied to the column and the elastase-related antigen in the eluate was quantitated by radioimmunoassay. Two peaks of antigen were detected, and their elution positions were identical to those obtained when active ${ }^{125}$ I-elastase was added to serum. No elastase-related antigen was detected in the position of the free enzyme.

\section{DISCUSSION}

In this study, the detection of elastase-related antigen has been used as a marker for PMN activation. Other cells, including platelets (30) and macrophages (31), contain enzymes with elastolytic activity, but these enzymes appear to be immunologically unrelated to PMN elastase. The levels of elastase-related antigen detected in the extracts of other cell types could be 


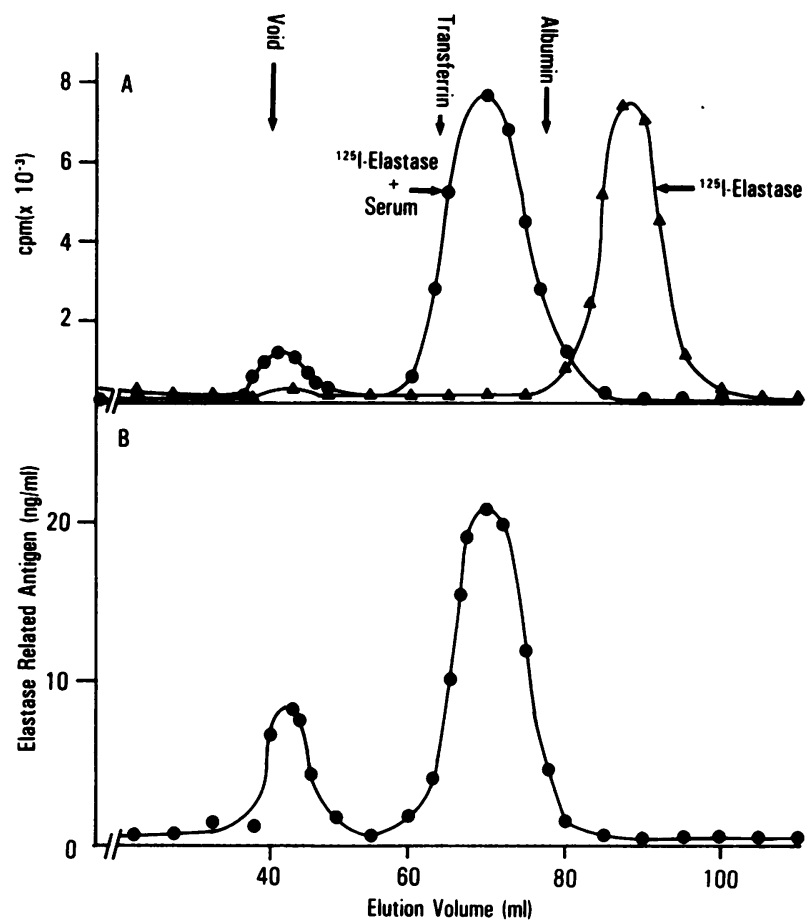

Figure 4 Interaction of leukocyte elastase with serum proteins. The elution profiles are from a $1.5 \times 90-\mathrm{cm}$ column of Sephadex G-100 equilibrated with $1.0 \mathrm{M} \mathrm{NaCl}, 0.05 \mathrm{M}$ Tris, $\mathrm{pH}$ 7.4. Panel A shows the elution of the radioactivity of free ${ }^{125}$ I-elastase $(\Delta-\Delta)$ that had been inactivated with DFP, and ${ }^{125} \mathrm{I}$-elastase incubated with serum for $30 \mathrm{~min}$ before application (- The elution positions of albumin and transferrin were established from the serum. Panel B. Plasma containing $10^{8} \mathrm{PMN} / \mathrm{ml}$ was recalcified and $0.3 \mathrm{ml}$ of the serum removed $1 \mathrm{~h}$ after clotting was applied to the column. The elastase-related antigen was quantitated by radioimmunoassay.

accounted for by less than a $1 \%$ PMN contamination. The sensitivity of the radioimmunoassay used was $\sim 0.5 \mathrm{ng} / \mathrm{ml}$ of elastase-related antigen, and this permitted ready quantitation of the elastase secreted from zymosan-stimulated PMN. In plasma, the mean level of elastase-related antigen detected was $25 \pm 6 \mathrm{ng} / \mathrm{ml}$. Anticoagulation of the plasma with chelating agents, citrate and EDTA, did not alter this level, whereas heparinized plasma contained threefold higher levels of elastase-related antigen. Immediate separation of the cells from the plasma and addition of protease inhibitors failed to change the plasma levels of the antigen. These results would suggest that consistent low levels of elastase-related antigen may exist in blood in vivo. Of greater significance was the observation that serum levels of elastase were markedly increased above plasma levels. With each of the seven normal donors examined, serum levels were higher than plasma levels, and the mean increase was 11.5-fold. Purified leukocyte elastase and serum produced par- allel inhibition slopes and both completely inhibited the radioimmunoassay, indicating that the leukocyte protease and the antigen detected in serum were immunochemically indistinguishable. Ohlsson and Olsson (32) detected $135 \mathrm{ng} / \mathrm{ml}$ of granulocyte elastase in serum but performed no comparison of plasma and serum levels of the enzyme. The serum level of elastase-related antigen of $288 \pm 125 \mathrm{ng} / \mathrm{ml}$ detected in this study is in reasonable agreement with their report. Further evidence suggesting release of leukocyte constituents during coagulation may be derived from the study of Bennett and Mohla (33), which indicated that serum lactoferrin levels were higher than plasma levels and were thus unacceptable for clinical analyses.

Increased serum levels of elastase occurred when isolated PMN were added to nonanticoagulated plasma or to recalcified ACD plasma. This suggests that the increase is independent of other cell types, and the observation that elastase release was of a similar magnitude in coagulating platelet-rich and platelet-poor plasma supports this conclusion. Serum also supported the release of elastase from PMN, indicating a stability of the activating factor(s) following coagulation. Addition of citrate to the serum blocked elastase release. This is consistent with a role of calcium in PMN secretion $(34,35)$, but divalent ions were in themselves insufficient to induce elastase liberation in the absence of plasma or serum. Addition of thrombin to PMNrich plasma in the absence of calcium also failed to induce elastase release, indicating that direct formation of the clot by thrombin was in itself insufficient to liberate the elastase. This suggests that earlier events in coagulation or events that occur in parallel with coagulation are responsible for inducing elastase secretion. It is required that such other events occur during the conversion of plasma to serum and would be sensitive to heparin and divalent ion chelation. Active secretion is suggested because PMN lysis and decreased viability were not detected in clotted samples.

Our interest in measuring elastase release relates to its role as a fibrinolytic enzyme. Elastase release was found to occur in concert with or shortly after clot formation, and maximum release occurred within 20 40 min after clot formation. This time frame would permit the coagulative arrest of bleeding before its potential participation in fibrinolysis. Molecular exclusion chromatography indicated that the elastaserelated antigen released from the PMN into serum ultimately formed high molecular weight complexes. $\alpha_{1}$-Antitrypsin and $\alpha_{2}$-macroglobulin are known inhibitors of leukocyte elastase (29) and the formation of these enzyme inhibitor complexes reasonably explains the gel filtration patterns observed. The ultimate formation of such complexes does not, however, pre- 
clude a physiological role for the released enzyme. The interaction of elastase with elastin has been shown to protect the enzyme from $\alpha_{1}$-antitrypsin (36). The binding of elastase to fibrin(ogen) or other potential substrates could also prolong its half-life.

Elastase is an enzyme of broad proteolytic specificity. In addition to fibrinogen, other coagulation factors (5), complement (37), fibronectin (38), plasminogen (39), and immunoglobulins (40) have been shown to be substrates for elastase. Degradation by elastase of elastin within lungs has been implicated in the tissue damage associated with emphysema (41), and high concentrations of the enzyme are also found within rheumatoid synovial tissue (42). Furthermore, it is reasonable to assume that PMN release of elastase is not selective, so that other proteases within the leukocyte granules would also be secreted. Thus, leukocyte release associated with blood coagulation may have broad physiological and pathophysiological implications.

\section{ACKNOWLEDGMENTS}

The helpful comments of Dr. Mark Ginsberg are greatly appreciated. The technical assistance of Janet Plescia and the preparation of the manuscript by Roberta Novak-Buhrman are gratefully acknowledged.

This work was supported by National Institutes of Health grant HL-17964.

\section{REFERENCES}

1. Nachman, R. L., and B. Ferris. 1968. Studies on human platelet protease activity. J. Clin. Invest. 47: 2530-2540.

2. Caviezel, O., M. Vollery, and A. Vannotti. 1964. Fibrinolyses leukocytaire. Schweiz. Med. Wochenschr. 94: 1016-1026.

3. Gans, H. 1965. Fibrinolytic properties of proteases derived from human, dog, and rabbit leukocytes. Thromb. Diath. Haemorrh. 10: 379-389.

4. Plow, E. F., and T. S. Edgington. 1975. An alternative pathway for fibrinolysis. I. The cleavage of fibrinogen by leukocyte proteases at physiologic $\mathrm{pH}$. J. Clin. Invest. 56: $30-38$.

5. Schmidt, W., R. Egbring, and K. Havemann. 1975. Effect of elastase-like and chymotrypsin-like neutral proteases from human granulocytes on isolated clotting factors. Thromb. Res. 6: 315-326.

6. Rulot, H. 1904. Intervention des leucocytes dans l'autolyse de la fibrine. Arch. Int. Physiol. Biochim. 1: 152-158.

7. Opie, E. L. 1907. Experimental pleurisy. Resolution of a fibrinous exsudate. J. Exp. Med. 9: 391-413.

8. Henry, R. L. 1965. Leukocytes and thrombosis. Thromb. Diath. Haemorrh. 13: 35-46.

9. Gottlob, R., M. Mattausch, K. Porschinski, and R. Kremar. 1978. The possible role of leukocytes in spontaneous and induced thrombolysis and some properties of leukocyte protease. In Progress in Chemical Fibrinolysis and Thrombolysis. R. M. Davidson, M. M. Samama, and P. C. Desnoyers, editors. Raven Press, New York. 3: 391411.

10. Barnhart, M. I. 1965. Importance of neutrophilic leu- kocytes in the resolution of fibrin. Fed. Proc. 24: 846853.

11. Hermann, G., and P. A. Miescher. 1965. Differentiation of leukocytic fibrinolytic enzymes from plasmin by the use of plasmatic proteolytic inhibitors. Int. Arch. Allergy Appl. Immunol. 27: 346-354.

12. Bilezikian, S. B., and H. L. Nossel. 1977. Unique pattern of fibrinogen cleavage by human leukocyte proteases. Blood. 50: 21-28.

13. Plow, E. F., and T. S. Edgington. 1978. Comparative immunochemical characterization of products of plasma and leukocyte protease cleavage of human fibrinogen. Thromb. Res. 12: 653-665.

14. Ohlsson, K., and I. Olsson. 1973. The neutral proteases of human granulocytes. Isolation and partial characterization of two granulocyte collagenases. Eur. J. Biochem. 36: 473-481.

15. Ohlsson, K., and I. Olsson. 1974. The neutral proteases of human granulocytes. Isolation and partial characterization of granulocyte elastases. Eur. J. Biochem. 42: 519-527.

16. Schmidt, W., and K. Havemann. 1974. Isolation of elastase-like and chymotrypsin-like neutral proteases from human granulocytes. Hoppe-Seyler's Z. Physiol. Chem. 355: 1077-1082.

17. Gramse, M., C. Bingenheimer, W. Schmidt, R. Egbring, and $K$. Havemann. 1978. Degradation products of $f-$ brinogen by elastase-like neutral protease from human granulocytes. J. Clin. Invest. 61: 1027-1033.

18. Wintroub, B. U., J. S. Coblyn, C. E. Kaempfer, and K. F. Austen. 1980. Cleavage of fibrinogen by the human neutrophil neutral peptide-generating protease. Proc. Natl. Acad. Sci. U. S. A. 77: 5448-5452.

19. Plow, E. F. 1980. The major fibrinolytic proteases of human leukocytes. Biochim. Biophys. Acta. 630: 47-56.

20. Ohlsson, K. 1971. Properties of leukocytic proteases. Clin. Chim. Acta. 32: 399-405.

21. Marguerie, G. A., E. F. Plow, and T. S. Edgington. 1979. Human platelets possess an inducible and saturable receptor for fibrinogen. J. Biol. Chem. 254: 5357-5363.

22. Janoff, A., and J. Scherer. 1968. Mediators of inflammation in leukocyte lysosomes. J. Exp. Med. 128: 11371151.

23. Visser, L., and E. R. Blout. 1972. The use of p-nitrophenyl-N-tert-butyloxycarbonyl-L-alaninate as a substrate for elastase. Biochim. Biophys. Acta. 268: 257260.

24. Taylor, J. C., and I. P. Crawford. 1975. Purification and preliminary characterization of human leukocyte elastase. Arch. Biochem. Biophys. 169: 91-101.

25. Chisari, F. V., J. L. Gerin, and T. S. Edgington. 1974 Immunochemistry of the hepatitis B virus: ${ }^{125} \mathrm{I}-\mathrm{HBAg}$ ligand. J. Immunol. 113: 543-553.

26. Plow, E. F., and T. S. Edgington. 1973. Immunobiology of fibrinogen. Emergency of neoantigenic expressions during physiological cleavage in vitro and in vivo. $J$. Clin. Invest. 52: 273-282.

27. Gay, R. J., R. B. McComb, and G. N. Bower, Jr. 1968. Optimal reaction conditions for human lactate dehydrogenase isoenzymes as they affect total lactate dehydrogenase activity. Clin. Chem. 14: 740-753.

28. Weber, K., and M. J. Osborn. 1969. The reliability of molecular weight determinations by dodecyl sulfate polyacrylamide gel electrophoresis. J. Biol. Chem. 244: 4406-4412.

29. Travis, J., R. Baugh, P. J. Giles, D. Johnson, J. Bowen, 
and C. F. Reilly. 1978. Human leukocyte elastase and cathepsin G. Isolation, characterization and interaction with plasma proteinase inhibitors. In Neutral Proteases of Human Polymorphonuclear Leukocytes. K. Havemann and A. Janoff, editors. Urban and Schwarzenberg, Baltimore, Md. 118-128.

30. Hornebeck, W., P. M. Starkey, J. L. Gordon, Y. Leghand, G. Pignaud, L. Robert, J. P. Caen, H. P. Ehrlich, and A. J. Barrett. 1980. The elastase-like enzyme of platelets. Thromb. Haemostasis. 42: 1681-1683.

31. Werb, Z., and S. Gordon. 1975. Elastase secretion by stimulated macrophages. Characterization and regulation. J. Exp. Med. 142: 361-377.

32. Ohlsson, K., and A. S. Olsson. 1978. Immunoreactive granulocyte elastase in human serum. Hoppe-Seyler's Z. Physiol. Chem. 359: 1531-1539.

33. Bennett, R. M., and C. Mohla. 1976. A solid-phase radioimmunoassay for the measurement of lactoferrin in human plasma: variations with age, sex and disease. $J$. Lab. Clin. Med. 88: 156-166.

34. Showell, H. J., P. H. Naccache, R. I. Sch'afi, and E. L. Becker. 1977. The effects of extracellular $\mathrm{K}, \mathrm{Na}^{+}$and $\mathrm{Ca}^{++}$on lysosomal enzyme secretion from polymorphonuclear leukocytes. J. Immunol. 119: 804-811.

35. Weissman, G., H. M. Korchaz, H. D. Perez, J. E. Smolen, I. M. Goldstein, and S. T. Hoffstein. 1979. The secretory code of the neutrophil. J. Reticuloendothel. Soc. 26: 687-700.
36. Reilly, C. F., and J. Travis. 1980. The degradation of human lung elastin by neutrophil proteinases. Biochim. Biophys. Acta. 621: 147-157.

37. Taylor, J. C., I. P. Crawford, and T. E. Hugli. 1977. Limited degradation of the third component (C3) of human complement by human leukocyte elastase (HLE): partial characterization of C3 fragments. Biochemistry. 16: 3390-3396.

38. McDonald, J. A., and D. G. Kelley. 1980. Degradation of fibronectin by human leukocyte elastase. J. Biol. Chem. 255: 8848-8858.

39. Moroz, L. A. 1981. Mini-plasminogen: a mechanism for leukocyte modulation of plasminogen activation by urokinase. Blood. 58: 97-104.

40. Solomon, A. 1978. Possible role of PMN proteases in immunoglobulin degradation and amyloid formation. In Neutral Proteases of Human Polymorphonuclear Leukocytes. K. Havemann and A. Janoff, editors. Urban and Schwarzenberg, Inc., Baltimore, Md. 423-436.

41. Janoff, A. 1978. Granulocyte elastase: role in arthritis and pulmonary emphysema. In Neutral proteases of Human Polymorphonuclear Leukocytes. K. Havemann and A. Janoff, editors. Urban and Schwarzenberg, Inc., Baltimore, Md. 390-417.

42. Saklatvala, J., and A. J. Barrett. 1980. Identification of proteinases in rheumatoid synovium. Detection of leukocyte elastase, cathepsin $G$ and other serine proteinases. Biochim. Biophys. Acta. 615: 167-177. 